Rafat Dowgier

\title{
WEJŚCIE W ŻYCIE I OBOWIAZYWANIE USTAWY PODATKOWEJ
}

\section{Wprowadzenie}

Podstawowym wymogiem obowiązywania aktu prawnego jest jego wejście w życie. Moment ten, aż do daty uchylenia lub wygaśnięcia, wyznacza czas, w którym ujęte $\mathrm{w}$ danym akcie prawnym przepisy prawne mogą być stosowane. Zagadnienie obowiązywania aktu prawnego ma szczególny wymiar w aspekcie ustaw podatkowych. Wynika to ze specyfiki materii podatkowej, w tym zwłaszcza z ograniczeń w zakresie nakładania obowiązku podatkowego oraz określania elementów konstrukcyjnych podatku. Zgodnie bowiem art. 84 i art. 217 Konstytucji RP, tak nakładanie podatków, jak i elementy ich konstrukcji musi regulować ustawa. Rzeczą kluczową $\mathrm{z}$ tego punktu widzenia jest więc ustalenie czasookresu obowiązywania ustawy podatkowej.

Ze wskazaną wyżej problematyką wiążą się dwie zasadnicze grupy zagadnień.

Pierwsza z nich dotyczy kwestii o charakterze zasadniczym, ustrojowym, związanych z naczelnymi zasadami stanowienia prawa. Zasady stanowienia (tworzenia) prawa podatkowego stanowią jedną $z$ kategorii zasad prawa podatkowego. Mają one techniczny charakter, odnoszący się do formułowania i systematyzowania przepisów podatkowych. Ze względu na jurydyczny charakter można je podzielić na zasady normatywne i pozanormwatywne. ${ }^{1}$ Podstawowe zasady legislacji znajdują umocowanie w przepisach prawa. W tym zakresie zwrócić należy uwagę na zasadę jawności wyrażoną w art. 88 ust. 1 Konstytucji RP, w świetle której warunkiem obowiązywania aktu prawnego jest jego prawidłowe ogłoszenie. Z problematyką tą wiąże się również kwestia zapewnienia odpowiedniego okresu vacatio legis w zakresie wprowadzanych rozwiązań. 2007, s. 12. 
Kolejna grupa zasad stanowienia prawa podatkowego wynika z przepisów prawa w sposób pośredni - jest więc konieczne ich odtworzenia w oparciu o normę o charakterze generalnym. Przykładem takiej sytuacji jest art. 2 Konstytucji RP zawierający zasadę demokratycznego państwa prawnego. Sama zasada państwa prawnego ma charakter generalny i jako taka bez watpienia oddziaływuje na tworzenie prawa podatkowego w Polsce. Można w jej ramach wyróżnić podzasady dotyczące wymagań co do bezpieczeństwa prawnego (zasada zaufania obywatela do państwa, w skład której wchodzą: zasada ochrony praw nabytych, zasada niedziałania prawa wstecz, zakaz wprowadzania zmian w prawie podatkowym w trakcie roku). Wskazane zasady w sposób bezpośredni kształtują czasookres obowiązywania prawa podatkowego.

Drugi ze wskazanych aspektów to kwestie czysto techniczne, legislacyjne, związane z konstrukcją przepisów ustawowych, które określają ich moment wejścia w życie i okres obowiązywania. Są to zatem normy skierowane do podmiotów tworzących prawo, których stosowanie stanowić ma gwarancję realizacji wskazanych wyżej zasad ogólnych. Podstawowym zbiorem tych reguł jest rozporządzenie Prezesa Rady Ministrów z dnia 20 czerwca 2002 r. w sprawie „Zasad techniki prawodawczej". ${ }^{2}$ W orzecznictwie podkreśla się, iż nie jest to akt normatywny, ale odzwierciedla standardy kultury prawnej. ${ }^{3} \mathrm{Na}$ szczególną uwagę, w analizowanym kontekście, zasługuje także ustawa z dnia 20 lipca 2000 r. o ogłaszaniu aktów normatywnych i niektórych innych aktów prawnych. ${ }^{4}$ Materia regulowana wskazanymi aktami będzie przedmiotem dalszych rozważań.

Celem niniejszego opracowania jest przedstawienie wybranych zagadnień związanych z problematyką wejścia w życie i obowiązywania ustawy podatkowej, z uwzględnieniem wskazanych wyżej aspektów i specyfiki prawa podatkowego. Można bowiem postawić tezę, iż ustawa, której przedmiotem jest materia podatkowa, wyróżnia się tak na etapie jej stanowienia, jak i stosowania w stopniu, który uzasadnia jej analizę, odrębnie od aktów normatywnych o charakterze podstawowym z innych gałęzi prawa. Odrębności te widoczne są także na płaszczyźnie czasookresu obowiązywania aktu prawnego, czyli przedziału czasowego, który rozpoczyna wejście w życie ustawy, a kończy data jej uchylenia lub wygaśnięcia.

\section{Moment wejścia w życie ustawy podatkowej}

Zgodnie z art. 88 ust. 1 Konstytucji warunkiem wejścia w życie ustaw, rozporządzeń oraz aktów prawa miejscowego jest ich ogłoszenie. Ogłoszenie oznacza

Dz.U. Nr 100, poz. 908 - dalej zwane w skrócie z.t.p.

Wyrok WSA z dnia 14 czerwca 2006 r., III SA/Wa 2433/05, LEX nr 229603.

Dz.U. Nr 62, poz. 718 z późn. zm. - dalej zwana w skrócie u.o.a.n. 
przekazanie informacji o treści aktu normatywnego jego adresatom. Zasady i tryb ogłaszania ustaw i innych aktów normatywnych określa ustawa o ogłaszaniu aktów normatywnych i niektórych innych aktów prawnych. Warunkiem wejścia w życie ustawy jest opublikowanie jej tekstu w urzędowym promulgatorze - Dzienniku Ustaw. Zaznaczyć przy tym trzeba, że do spełnienia warunku opublikowania aktu normatywnego konieczne jest nie tylko wydanie danego numeru Dziennika Ustaw, ale także jego udostępnienie, a więc przynajmniej skierowanie go do rozpowszechniania. Nie ma natomiast znaczenia, czy adresaci skorzystali z możliwości zapoznania się z tekstem ogłoszonego we właściwy sposób aktu normatywnego. ${ }^{5}$

Powyższe jest realizacją zasady pewności prawa nakazującej przestrzeganie reguły jawności, która wyraża się obowiązkiem publikacji między innymi aktów prawa podatkowego. Podatnik nie może przestrzegać prawa, którego z przyczyn obiektywnych (brak publikacji) nie mógł poznać.

Warunkiem skutecznego wejścia w życie aktu normatywnego, obok jego opublikowania, jest także zachowanie odpowiedniego okresu vacatio legis. W tym kontekście respektowanie zasady jawności jest konieczne, gdyż po wprowadzeniu w życie nowych regulacji podatkowych podatnik musi mieć zagwarantowany czas (vacatio legis) na przystosowanie się do nowej rzeczywistości podatkowej oraz bezpieczne podjęcie decyzji dotyczących dalszego postępowania. ${ }^{6}$

Podmioty przygotowujące projekty aktów prawnych, już na tym etapie procesu prawodawczego, powinny ustalić termin ich wejścia w życie. Wymóg taki stawiają postanowienia z.t.p. W tym miejscu można wskazać, że zgodnie z $§ 38$ ust. 1 pkt 2 wskazanego zbioru zasad, przepisy o wejściu w życie ustawy powinny znajdować się w części „przepisy końcowe”. Zasadą jest, że w ustawie zamieszcza się przepis określający termin jej wejścia w życie, chyba że termin ten określają odrębne przepisy ustawy wprowadzającej (§ 43). Ustawa powinna wchodzić w życie w całości w jednym terminie. Nie różnicuje się terminów wejścia w życie poszczególnych przepisów ustawy, a odstępstwo od tego rozwiązania może nastapić tylko w przypadku przepisów zmieniających, uchylających, przejściowych i dostosowujących (§ 44).

Odpowiednie vacatio legis jest warunkiem realizacji zasady zaufania obywateli do państwa i pewności prawa. Trybunał Konstytucyjny uznał, że minimalny okres vacatio legis nie powinien być krótszy niż 14 dni, co nie oznacza, że - stosownie do okoliczności - termin ten nie powinien być dłuższy. Dotyczy to zwłaszcza norm prawnych, które regulują zagadnienia gospodarcze (w tym finansowe i podatkowe) i wymagają dostosowania działalności gospodarczej do nowych okoliczności. Oby-

$5 \quad$ Zob. wyrok TK z dnia 20 grudnia 1999 r., K 4/99, OTK 1999, nr 7.

6 A. Gomułowicz, Zasady podatkowe wczoraj i dziś, Warszawa 2001, s. 31. 
watel musi mieć pewność należytego zabezpieczenia interesów w toku oraz układania swoich spraw w zaufaniu, że „nie naraża się na niekorzystne skutki prawne swoich decyzji i działań, niemożliwe do przewidzenia w chwili podejmowania tych decyzji i działań. ${ }^{7} \mathrm{~W}$ związku z powyższym termin 14-dniowy należy uznać za punkt wyjścia i powinien być on modyfikowany odpowiednio do treści i charakteru przepisów prawa. Ocena „odpowiedniości” vacatio legis zależy od innych zasad i wartości konstytucyjnych, odnoszących się do danej regulacji prawnej. Argument ważnego interesu publicznego może - wyjątkowo - uzasadniać ograniczenie lub nawet rezygnację $\mathrm{z}$ ustanowienia vacatio legis. ${ }^{8} \mathrm{~W}$ szczególności, jak wskazał Trybunał Konstytucyjny w orzeczeniu z dnia 16 czerwca 1999 r. ${ }^{9}$, w sytuacji, gdy istnieje możliwość zapoznania się z nowymi przepisami i istnieją możliwości adaptacyjne, ważny interes publiczny przemawia za uznaniem, iż 7-dniowa vacatio legis jest „odpowiednia”.

Skrócenie zwykłego okresu vacatio legis przy wprowadzaniu zmian prawa podatkowego jest możliwe, gdy wymaga tego przestrzeganie prawa i ochrona interesów finansowych państwa. Równowaga finansowa państwa stanowi wartość chronioną konstytucyjnie. Wynika ona $\mathrm{z}$ całokształtu regulacji zawartych $\mathrm{w}$ rozdziale $\mathrm{X}$ Konstytucji, zwłaszcza zaś z art. 216 oraz art. 220, ale także z art. 1, który stanowi, że Rzeczpospolita jest dobrem wspólnym wszystkich obywateli. Argument ważnego interesu publicznego może wyjątkowo uzasadniać ograniczenie lub nawet rezygnację z ustanowienia vacatio legis. Za taki ważny interes publiczny można bez wątpienia uznać dążenie ustawodawcy do przeciwstawienia się oszustwom i nadużyciom podatkowym, prowadzącym do uchylenia się od obowiązku uiszczania należnych podatków. ${ }^{10} \mathrm{~W}$ zakresie ustaw podatkowych zdarzały się sytuacje, gdy okres $v a$ catio legis był krótszy od standardowego, np. część opublikowanych w Dzienniku Ustaw Nr 249, poz. 1828 z dnia 29 grudnia 2006 r. przepisów ustawy z dnia 7 grudnia 2006 r. o zmianie ustawy o podatkach i opłatach lokalnych weszła w życie już dnia 1 stycznia 2007 r. Sytuację tę należy uznać jednak za wyjątkową i nie zmienia ona faktu, że modyfikowanie momentu wejścia w życie ustawy podatkowej poprzez skrócenie podstawowego okresu vacatio legis w praktyce jest rzadko wykorzystywane.

Jak już wspomniano, co do zasady, okres vacatio legis powinien być dostosowany do materii objętej nowo wprowadzaną regulacją. W tym kontekście w zakresie podatków o tak zwanym otwartym stanie faktycznym (przede wszystkim dochodowe), sformułowano zasadę, zgodnie z którą nowelizacje tych świadczeń powinny być ogłaszane co najmniej na miesiąc przed końcem poprzedniego roku podatko-

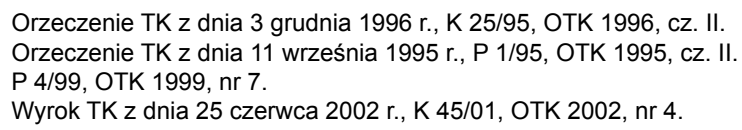


wego. Powyższe stanowisko potwierdzono w wyroku Trybunału Konstytucyjnego z dnia 15 lutego 2004 r. ${ }^{11}$, w którym zakwestionowano, jako niezgodne z zasadą państwa prawnego, wprowadzenie z dniem 1 stycznia 2005 r. 50-procentowej stawki podatkowej od dochodów osobistych powyżej 600 tys. zł w stosunku rocznym, na mocy ustawy z dnia 18 listopada 2004 r. o zmianie ustawy o podatku dochodowym od osób fizycznych oraz o zmianie niektórych innych ustaw ${ }^{12}$, ogłoszonej w dniu 13 grudnia 2004 r. Powołując się na wypływającą z zasady demokratycznego państwa prawnego zasadę zaufania, Trybunał stwierdził, że „w odbiorze podatników mogło powstać przekonanie o stabilności obciążeń podatkiem dochodowym, a w szczególności o jego trójszczeblowej skali. Nie zmieniły zasadniczo tego przekonania doniesienia prasowe o projektach wprowadzenia istotnych zmian skali opodatkowania czy wprowadzenia podatku liniowego, ponieważ prace w tym zakresie nie wykroczyły poza fazę postulatów, a zaskarżone w niniejszej sprawie przepisy ustawy nowelizującej z 18 listopada 2004 r. traktowane były - do chwili jej podpisania przez Prezydenta i ogłoszenia - jako kontrowersyjne. Dlatego należy przyjąć, że o nowej stawce podatkowej, obowiązującej w 2005 r., podatnicy mogli się dowiedzieć dopiero 13 grudnia 2004 r., czyli z chwilą ogłoszenia ustawy nowelizującej w Dzienniku Ustaw, a zatem bez miesięcznego wyprzedzenia".

Wobec zwiększonego obciążenia, jakie dla niektórych podatników niosło ze sobą wprowadzenie 50-procentowej stawki podatkowej z dniem 1 stycznia 2005 r., ogłoszenie tej zmiany dopiero 13 grudnia 2004 r. spowodowało, że vacatio legis była zbyt krótka. Stanowiło to naruszenie zasady zaufania do państwa i stanowionego przez nie prawa i przez to było niezgodne $\mathrm{z}$ art. 2 Konstytucji.

\section{Prawo podatkowe nie działa wstecz}

Zakaz wstecznego działania prawa (zasada lex retro non agit) jest jednym $\mathrm{z}$ fundamentów prawodawstwa podatkowego. Wsteczne działanie prawa polega na tym, że normy prawne nakazują nawiązywać do czynów, stanów rzeczy lub zdarzeń, które miały miejsce w przeszłości, przed wejściem w życie owych norm. Ustawa działa z mocą wsteczna, kiedy początek jej stosowania pod względem czasowym został ustalony na moment wcześniejszy od momentu, w którym ustawa zaczęła obowiązywać (została nie tylko uchwalona, lecz także prawidłowo ogłoszona w organie promulgacyjnym). ${ }^{13}$ Istotą retroaktywności jest okoliczność, że nowo ustanowione normy modyfikują zaistniałe już i skonsumowane skutki stosowania norm wcześniejszych. ${ }^{14}$

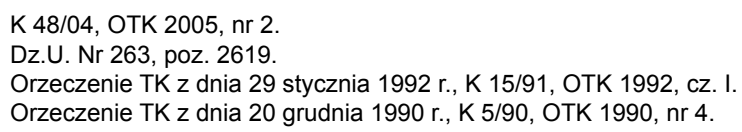


Analizowana zasada jako dyrektywa legislacyjna skierowana pod adresem organów stanowiących prawo zawiera w swej treści zakaz stanowienia norm prawnych, które stosowane byłyby do zdarzeń (rozumianych sensu largo) mających miejsce przed wejściem w życie nowo ustanowionych regulacji i z którymi prawo nie wiązało dotąd skutków prawnych przewidzianych tymi normami. Norma nie działa wstecz, jeżeli na jej podstawie należy dokonywać kwalifikacji zdarzeń, które wystąpiły po jej wejściu w życie. ${ }^{15}$

Respektowanie zasady lex retro non agit $\mathrm{w}$ praktyce oznacza, że:

- istnieje zakaz stanowienia rozwiązań prawnopodatkowych, które nakazywałyby stosować nowo ustanowione normy prawne do zdarzeń, które miały miejsce przed ich wejściem w życie i z którymi prawo podatkowe nie wiązało dotąd skutków prawnych;

- postępowanie podatnika podejmowane pod rządami obowiązującego prawa podatkowego i związane z nimi następstwa muszą być również uznane przez późniejszy porządek prawny - czyli przez nową regulację. ${ }^{16}$

Warto zwrócić uwagę, że zasada lex retro non agit nie ma charakteru bezwzględnego i w pewnych, ściśle określonych wypadkach, możliwe jest od niej odejście. Wypadki te, na co niejednokrotnie zwracał uwagę Trybunał Konstytucyjny, muszą mieć wyjątkowy charakter i uzasadnienie w szczególnych okolicznościach, gdy przemawia za tym inna zasada konstytucyjna, np. sprawiedliwości społecznej. W orzecznictwie Trybunału Konstytucyjnego podkreśla się, że nieretroaktywność dotyczy tylko takich regulacji normujących prawa i/lub obowiązki obywateli, które pogarszają ich sytuację $\mathrm{w}$ stosunku do stanu poprzedniego, np. poprzez ograniczenie praw lub powiększenie zobowiązań. ${ }^{17} \mathrm{Nie}$ ma natomiast zakazu (w każdym razie do regulacji socjalnych bądź majątkowych), by nowe normy przekreślały możliwość dalszego korzystania z regulacji ustanowionych wcześniej.

Dopuszczalność retroaktywności prawa wynika z art. 5 u.o.a.n., zgodnie z którym nadanie aktowi normatywnemu wstecznej mocy obowiązującej jest możliwe, jeżeli zasady demokratycznego państwa prawnego nie stoją temu na przeszkodzie. Biorąc powyższe pod uwagę, wydaje się, że żadna z naczelnych konstytucyjnych zasad nie stoi na przeszkodzie nadaniu mocy wstecznej takim regulacjom prawnym, które wprowadzają szeroko pojęte preferencje podatkowe (ulgi, zwolnienia), czy też skutkują obniżeniem stawki podatkowej. Kluczowe jest jednak w takim przypadku stworzenie przepisów przejściowych, które uregulują sytuację podmiotów, wobec których zmienione regulacje będą działały z mocą wsteczną.

15 Orzeczenie TK z dnia 28 maja 1986 r., U 1/86, OTK 1986, cz. II.

16 A. Gomułowicz, Zasady podatkowe..., op. cit., s. 30.

17 Orzeczenie TK z dnia 29 stycznia 1992 r., K 15/91, OTK 1992, cz. I. 
Z powyższym korespondują zapisy „Zasad techniki prawodawczej”. W § 51 zawarto bowiem regulacje, które doprecyzowują, w jaki sposób nadawać ustawie lub jej części moc wsteczną. Obok wskazania samego technicznego zapisu, który powinien być w tym zakresie wykorzystywany, podkreślono, iż „Przepisy ustawy inne niż te, którym przepisy końcowe nadały wsteczną moc obowiązująca, a posiadające moc wsteczną wynikającą z ich treści i odnoszące się do zdarzeń lub stanów rzeczy, które powstały przed dniem wejścia w życie ustawy, redaguje się w sposób jednoznacznie wskazujący te zdarzenia lub stany rzeczy". W związku z tym stwierdzić należy, iż nadanie przepisom mocy wstecznej chociaż jest teoretycznie dopuszczalne, nie jest rzeczą prostą $\mathrm{z}$ technicznego punktu widzenia. Jasno należy określić, w stosunku do jakich zdarzeń nakazuje się stosować dane przepisy. ${ }^{18}$

Zakaz retroaktywności prawa można także rozumieć szerzej - nie tylko jako zakaz stanowienia norm prawnych, które nakazywałyby stosować nowo ustanowione prawo do zdarzeń z okresu sprzed ich wejścia w życie i z którymi prawo nie wiązało dotąd skutków prawnych (zasada lex retro non agit we właściwym znaczeniu), lecz także jako zakaz stanowienia intertemporalnych reguł, które określałyby treść stosunków prawnych powstałych pod rządami dawnych norm, a trwających w okresie wejścia w życie nowo ustanowionych, jeżeli reguły te wywoływałyby ujemne prawne (a w konsekwencji społeczne) następstwa dla bezpieczeństwa prawnego i poszanowania praw nabytych. ${ }^{19}$

Zauważyć należy, iż Trybunał Konstytucyjny podkreślał w swoim orzecznictwie, że zakaz działania prawa wstecz obowiązuje we wszystkich dziedzinach prawa, ale odnosi się przede wszystkim do stanowienia przepisów karnych. ${ }^{20}$ Znalazło to bezpośredni wyraz w art. 42 ust. 1 Konstytucji. Podobnego bezpośredniego zapisu nie ma, jeżeli chodzi o prawo daninowe, chociaż jego potrzeba nie może budzić wątpliwości. ${ }^{21} \mathrm{~W}$ tym kontekście wskazać jednak należy, iż nadawanie mocy wstecznej przepisom podatkowym miało w praktyce miejsce. Tego rodzaju sytuacja związana była np. ustawą z dnia 8 maja 2003 r. o zmianie ustawy o pracowniczych ogrodach działkowych, ustawy o podatku rolnym oraz ustawy o podatkach i opłatach lokalnych ${ }^{22}$, która weszła $\mathrm{w}$ życie $\mathrm{z}$ dniem ogłoszenia i wprowadziła z mocą wsteczną od dnia 1 stycznia $2003 \mathrm{r}$. zwolnienia w podatku rolnym oraz podatku od nieruchomości dla Polskiego Związku Działkowców. Szczególnym wydarzeniem

18 Przykładowe rozwiązania w tym zakresie wskazano (w:) J. Warylewski (red.), Zasady techniki prawodawczej. Komentarz do rozporządzenia, Warszawa 2003, s. 245.

19 Orzeczenie TK z dnia 30 listopada 1988 r., K 1/88, OTK 1988, cz. I.

20 Orzeczenie TK z dnia 12 stycznia 1995 r., W 12/94, OTK 1995, cz. I.

21 Waga tego zagadnienia została dostrzeżona w ustawach zasadniczych innych państw europejskich, np. w Konstytucji Federacji Rosyjskiej, w której w art. 57 znalazł się zapis, zgodnie z którym ustawy wprowadzające nowe podatki lub pogarszające sytuację podatników nie działają wstecz. Podobnie w art. 78 ust. 2 Konstytucji Grecji wskazuje się, iż „Żaden podatek ani żadne inne obciążenie finansowe nie mogą zostać wprowadzone przez ustawę z mocą wsteczna, sięgającą poza rok finansowy poprzedzający rok wprowadzenia podatku". Dz.U. Nr 110, poz. 1039. 
było także wejście z mocą wsteczną od początku 1992 roku ustawy z dnia 15 lutego 1992 r. o podatku dochodowym od osób prawnych. Były to jednak wyjątki potwierdzające regułę, iż przepisy podatkowe nie obowiązującą z mocą wsteczną.

\section{Zakaz wprowadzania zmian w prawie podatkowym w czasie trwania roku podatkowego}

Elementem zasady zaufania, akcentowanym w sposób szczególny na gruncie prawa podatkowego, jest zakaz zmiany przepisów z tej gałęzi prawa w trakcie trwania roku podatkowego. Reguła ta nie dotyczy jednak wszystkich podatków, a jedynie tych o tzw. otwartym stanie faktycznym, czyli takich, których ustalenie jest możliwe dopiero po zakończeniu pewnego okresu rozliczeniowego (np. roku podatkowego) - chodzi tu przede wszystkim o podatki dochodowe. ${ }^{23}$ Po drugie, wskazany zakaz bez wątpienia dotyczy jedynie tych regulacji prawnych, które pogarszają sytuację podatnika, nie wyklucza natomiast zmiany w trakcie roku podatkowego czy innego okresu rozliczeniowego, ,reguł gry” w ten sposób, iż sytuacja podatnika byłaby uprzywilejowana w porównaniu do tej przed zmianami. Przyjąć też należy, iż zmiana w trakcie roku jest dopuszczalna, gdy jej celem jest eliminacja ewidentnych błędów ustawodawcy. W każdym razie odstępstwa od zakazu zmian przepisów podatkowych w trakcie roku podatkowego należy traktować jako wyjątek, który nie powinien być nadużywany.

Przedmiotowa zasada znajduje swoje źródło w wyprowadzonej z art. 2 Konstytucji zasadzie ochrony ,interesów w toku”, która zapewnia ochronę jednostki w sytuacjach, w których rozpoczęła ona określone przedsięwzięcia na gruncie dotychczasowych przepisów. Nakaz ochrony interesów w toku nie ma charakteru bezwzględnego. Ma jednak szczególne, kategoryczne znaczenie w prawie podatkowym. Konstruując kształt systemu podatkowego obowiązującego docelowo w danym roku podatkowym, ustawodawca wyznacza pewne granice czasowe, w których jednostka będzie mogła realizować określone przedsięwzięcia według z góry ustalonych reguł, w zaufaniu, że nie zostaną one zmienione. Powinien więc dawać gwarancję, że dane przedsięwzięcie, często rozłożone w czasie, zostanie dokończone na zasadach nie gorszych niż w dacie jego rozpoczęcia.

23 W niektórych państwach europejskich podatkom nadaje się charakter roczny, co w zasadzie uniemożliwia ich zmiany w trakcie roku podatkowego. Skrajnym przypadkiem jest Belgia, gdzie zgodnie z art. 171 Konstytucji Belgii, podatki uchwala się corocznie, a przepisy, na podstawie których są realizowane, również mają roczny okres obowiązywania. Oznacza to, że do pobierania ich w kolejnym roku konieczne jest podjęcie inicjatywy prawodawczej. W tym kontekście widoczne jest powiązanie podatków z budżetem, a ściślej - procedury związanej z podejmowaniem ustawy budżetowej i ustawy podatkowej. 
Znaczenie analizowanej zasady, jako fundamentalnej dla prawa podatkowego, podkreślił Trybunał Konstytucyjny w orzeczeniu z dnia 27 lutego $2002 \mathrm{r}^{24}$ Wyraził w nim stanowisko, zgodnie z którym na gruncie Konstytucji z dnia 2 kwietnia 1997 r. aktualny pozostaje pogląd wyrażony we wcześniejszym orzecznictwie w nawiązaniu do zasady demokratycznego państwa prawnego, że w zasadzie nie jest dopuszczalne dokonywanie zmian samych obciążeń podatkowych $\mathrm{w}$ ciagu roku podatkowego.

Orzeczenie to, posługując się sformułowaniem „w zasadzie nie jest dopuszczalne", pozostawia jednak furtkę, która umożliwia w wyjątkowych sytuacjach zmiany konstrukcji podatkowych w trakcie roku podatkowego. Jak już jednak na wstępie stwierdzono, będą to sytuacji niezmiernie rzadkie.

\section{Ochrona praw słusznie nabytych}

Ochrona praw słusznie nabytych jest jedną z podstawowych wartości państwa prawnego i powinna obowiązywać również w prawodawstwie podatkowym. W tym przypadku bezpieczeństwo prawne podatnika polega na pewności, że prawa podmiotowe, uzyskane zgodnie z przepisami ustawy podatkowej i zasadami słuszności, nie zostaną w sposób niespodziewany i bez uzasadnionej racji przez ustawodawcę podatkowego zniesione bądź ograniczone. Zasada ochrony praw nabytych zakazuje zatem arbitralnego znoszenia lub ograniczania praw podmiotowych przysługujących jednostce.

Zasada ochrony praw nabytych może być rozpatrywana w dwóch płaszczyznach: aksjologicznej i normatywnej, czemu dał wyraz w swoim orzecznictwie Trybunał Konstytucyjny.

W sensie aksjologicznym omawiana zasada stanowi podstawę bezpieczeństwa prawnego obywateli oraz wiarygodności państwa i jego organów w stosunkach z obywatelami, których zaufanie jest warunkiem skuteczności i wykonywania władzy państwowej. Ochrona praw nabytych jest zadaniem państwa, a zarazem podstawą ładu prawnego w państwie prawa. Jej respektowanie ma ponadto zasadnicze znaczenie dla stanu świadomości prawnej obywateli, którzy w sytuacji odebrania przyznanych im uprawnień tracą szacunek dla samej idei prawa, nie znajdując w ustawach niezawodnego źródła swoich praw. ${ }^{25}$

W znaczeniu normatywnym zasada ochrony praw nabytych stanowi źródło względnej trwałości uzyskanych uprawnień, polegającej na tym, że ochronie przed $25 \begin{aligned} & \text { M. Wyrzykowski, Zasada demokratycznego państwa prawnego, (w:) W. Sokolewicz (red.), Zasady podstawowe } \\ & \text { polskiej Konstytucji, Warszawa 1998, s. 84. }\end{aligned}$ 
likwidacją i uszczupleniem podlegają prawa uzyskane słusznie i pod warunkiem, że nie utraciły mocy ich ratio legis w nowym układzie stosunków społecznych. ${ }^{26}$

Zasada ochrony praw nabytych nie ma charakteru bezwzględnego, czyli absolutnego (relatywizm zasady ochrony praw nabytych). Nie obejmuje ona praw nabytych niesłusznie (niesprawiedliwie), które naruszają zasadę sprawiedliwości. W szczególności w orzeczeniu z dnia 22 sierpnia 1990 r. ${ }^{27}$ Trybunał Konstytucyjny wyraził pogląd, zgodnie z którym regulacja znosząca dotychczasowe uprzywilejowanie, ,nie mające rzeczowego i sprawiedliwego w odczuciu społecznym uzasadnienia", stanowi wprawdzie ingerencję w prawa nabyte, ale istotą tej ingerencji jest przywrócenie sytuacji wymaganej przez zasadę sprawiedliwości społecznej. Zauważyć jednak należy, iż zasada sprawiedliwości społecznej jest trudna do zobiektyzowania i bywa różnie pojmowana w różnych środowiskach społecznych, co uzasadnia ostrożne jej stosowanie jako usprawiedliwienia naruszenia zasady ochrony praw nabytych.

Dopuszczalne jest także wycofanie się przez państwo z wadliwych unormowań, które nie naruszały zasady sprawiedliwości. Działanie takie musi być jednak ujęte w określone ramy, których przekroczyć nie można. Nie wyklucza się zatem zmiany, niekorzystnej dla pewnej grupy obywateli, istniejącej regulacji prawnej, jeżeli spełnione są określone przesłanki. Ograniczenie, a nawet pozbawienie obywatela prawa podmiotowego jest możliwe, jeżeli wymaga tego ważny interes społeczny, lecz tylko w niezbędnym zakresie i pod warunkiem pełnego wyrównania (ekwiwalentność) praw (korzyści) utraconych. Dopuszczalność wycofania się przez ustawodawcę z błędnych unormowań została wyraźnie uznana przez Trybunał, który stwierdził, że ustawodawca może negatywnie ocenić wcześniejsze rozwiązania legislacyjne. Może więc także wyciągnąć wnioski, zwłaszcza w odniesieniu do przepisów obciążonych rażącymi wadami. Jednak tego rodzaju operacja powinna być przeprowadzona w sposób maksymalnie chroniący bezpieczeństwo prawne zainteresowanych osób i nie powinna ich zaskakiwać. ${ }^{28}$

Obywatel powinien liczyć się ze zmianą prawa wynikającą ze zmiany stosunków społecznych i gospodarczych. Ryzyko związane z wszelką działalnością gospodarczą obejmuje również ryzyko niekorzystnych zmian systemu prawnego, przy czym kluczowe w tym kontekście jest ustalenie horyzontu czasowego działań podejmowanych przez jednostkę w danej sferze życia. Im dłuższa perspektywa czasowa podejmowanych działań, tym silniejsza powinna być ochrona zaufania do państwa

$26 \quad$ Ibidem

27 K 7/90, OTK 1990, nr 1.

28 M. Wyrzykowski, Zasada demokratycznego..., op. cit., s. 87. 
i do stanowionego prawa, na co niejednokrotnie zwracał uwage w swoich orzeczeniach Trybunał Konstytucyjny. ${ }^{29}$

Na gruncie prawa podatkowego zasada ochrony praw nabytych najczęściej dotyka regulacji wprowadzających przywileje podatkowe (ulgi i zwolnienia). W wyroku z dnia 27 lutego 2002 r. ${ }^{30}$ Trybunał Konstytucyjny wskazał, w kontekście utrzymania lub cofnięcia zwolnień podatkowych, na domniemanie względnej swobody regulacyjnej ustawodawcy w zakresie udzielanych zwolnień. Podkreślono, że podatnikom podatku dochodowego od osób fizycznych nie może być przypisane bezterminowo „prawo do zwolnień podatkowych” określonego typu, wyprowadzane wyłącznie $\mathrm{z}$ faktu posiadania tego typu ustawowych zwolnień w poprzednim okresie czy też w znacznej części konkretnego roku podatkowego. Nie jest więc w tej sytuacji możliwe objęcie określonych zwolnień podatkowych zasięgiem bezwarunkowo i niezmiennie chronionych konstytucyjnie ,praw niewadliwie nabytych”, znajdujących „trwałą" ochronę w obliczu potencjalnych i motywowanych między innymi ochroną równowagi budżetowej zmian ustawodawstwa podatkowego. Dla przyjęcia konstytucyjnego wymogu takiej ochrony nie wystarcza też postulat sprawiedliwości społecznej, odniesiony do ochrony grupowego interesu podatników.

\section{Wnioski}

Poczynione rozważania pozwalają stwierdzić, że zagadnienie okresu obowiązywania ustawy podatkowej nie ma wymiaru czysto technicznego, sprowadzającego się do zastosowania odpowiedniej techniki prawodawczej. Wręcz przeciwnie, określając moment wejścia w życie oraz uchylenia ustawy podatkowej, należy wyjść od podstawowych zasad prawa podatkowego, które odnoszą się do kwestii stanowienia przepisów prawnych z tej gałęzi prawa.

Fundament, na którym powinien opierać się proces ustawodawczy, składa się z zasady zaufania i pewności prawa. To one wyznaczają granice działalności legislatora, który tworząc projekt ustawy podatkowej, musi zwrócić uwagę na jego zgodność zwłaszcza z normami konstytucyjnymi. W tym kontekście kluczowe znaczenie mają prawidłowe ogłoszenie ustawy oraz określenie momentu jej wejścia w życie z zachowaniem odpowiedniego okresu vacatio legis. „Odpowiedniego”, co oznacza, że w przypadku podatków rocznych będzie to przynajmniej 1 miesiąc, a w odniesieniu do pozostałych podatków standardowy okres 14 dni. Zauważyć przy tym należy, iż chociaż teoretycznie nawet termin podstawowy może ulec zmianie, czy nawet przepisom można nadać wsteczną moc obowiązująca, to tego rodzaju przy- 
padki w prawie podatkowym należy uznać za wyjątkowe. Generalną przesłanką stosowania tego rodzaju zabiegów legislacyjnych jest zakaz działania na szkodę podatnika. Oznacza to w praktyce, że skrócenie podstawowego okresu vacatio legis, czy ewentualne nadanie przepisom ustawy podatkowej wstecznej mocy obowiązywania, możliwe jest przy wprowadzaniu preferencji podatkowych, przede wszystkim w postaci ulg i zwolnień.

W przypadku ustaw podatkowych można stwierdzić, że powinny cechować się one względną stabilnością, rozumianą jako zakaz ingerowania $\mathrm{w}$ ich treść $\mathrm{w}$ podatkowym okresie rozliczeniowym. W związku z tym można mówić o generalnym zakazie zmian w prawie podatkowym w trakcie roku podatkowego, który odnosić należy do podatków o tzw. otwartym stanie faktycznym, czyli takich, których ustalenie jest możliwe dopiero po zakończeniu pewnego okresu rozliczeniowego (roku podatkowego). W przypadku modyfikowania aktów regulujących te podatki zmiany powinny wchodzić w życie najwcześniej z początkiem kolejnego roku, przy czym i od tej zasady są wyjątki. Dotyczą one po pierwsze, wprowadzania regulacji prawnych, które nie pogarszają sytuacji podatnika, po drugie - takich, które mają eliminować rażące błędy ustawodawcy.

Stabilność prawa podatkowego to również ochrona praw nabytych. Zasada ta ogranicza ustawodawcę we wprowadzaniu nowych regulacji, które znosiłyby przywileje podatkowe, lecz ograniczenie to nie ma charakteru bezwzględnego. W szczególności ingerencja ustawodawcy w nabyte uprawnienia podatkowe może wynikać $\mathrm{z}$ ich oceny jako niezasadnych i naruszających zasadę sprawiedliwości społecznej. Wskazana norma dopełnia katalog zasad, które kształtują czas obowiązywania ustawy podatkowej. 


\title{
THE ISSUE OF COMING INTO FORCE AND BINDING FORCE OF A TAX ACT
}

\author{
SUMMARY
}

A basic requirement of binding force of legal act is it's coming into force. There are two principle groups of problems connected with this issue. The first one refers to matter of basic, constitutional and structural character connected with prime principles of law constituting. In the context of tax law, the following rules apply: prohibition of introducing changes applying to the running year, protection of laws rightly acquired and the rule of prohibition of retroactive tax laws. Second group of problems is of technical and legislative character connected with the construction of legal regulations, which define the moment of entry into force and period of a binding force of the law.

The aim of the present elaboration is to present the above mentioned subject matter with respect to specificity of the tax law.

It seems that the law concerning tax issues differs from other normative acts of general nature in other branches of law. The differences can be observed in the phase of the tax law passing, as well as in the phase of its application, and as such, they justify the undertaken analysis. 